\title{
FACTORS AFFECTING INSOLE USAGE IN PATIENTS WITH PES PLANUS
}

\author{
Erem Murat, ${ }^{1}$ Acikgoz Tahsin, ${ }^{2}$ Tastekin Nurettin, ${ }^{3}$ Sut Necdet ${ }^{4}$ \\ ${ }^{1}$ Trakya University, Faculty of Medicine, Department of Orhopedics and Traumatology, Edirne, Turkey \\ ${ }^{2}$ Prosthetics and orthotics technician, Prosthetics and Orthotics Production Center, Edirne, Turkey \\ ${ }^{3}$ Trakya University, Faculty of Medicine, Department of Physical Medicine and Rehabilitation, Edirne, Turkey \\ ${ }^{4}$ Trakya University, Faculty of Medicine, Department of Biostatistics, Edirne, Turkey
}

Primljen/Received 05. 07. 2018. god.

Abstract: Introduction: Insoles and exercise programs are the main treatment methods for pes planus patients. Insole using may prevent the formation of pain in daily activities as well as increasing the quality of walking. The aim of this study was to investigate insole usage time and the factors affecting this situation in patient with pes planus. Materials and Methods: 136 patients with pes planus who were prescribed an insole, included in the study. We invited patients to participate in a telephone survey. Patients' demographics, insole usage time, reasons to quit and the quitting time were questioned. Insole usage rates and the demographic data of patients were compared. Results: Of the 136 patients included in the present study, 80 were women $(59 \%)$ and 56 were male (31\%). 86 of these patients used an insole six months and over, 15 of them used shorter than six months and 35 of them bought the insoles but they didn't use it $(63 \%, 11 \%$ and $26 \%$ respectively ). The average age of patients who used insoles was $32.80 \pm 18.14$ and who did not use insoles was $40.77 \pm 12.54(p=0.04) .33 .8$ percent of women and 14.3 percent of men did not use insoles. This difference is statistically significant $(p=0.04)$. We did not find any significant relationship between height, weight, body mass index values and usage of insoles $(p>0: 05)$. Conclusion: The use of insoles in treating patients with pes planus is widely accepted and may be affected by the demographics such as gender and age. Besides wearing comfort, female sex and older age should be considered that may affect the use of insoles.

Key words: Pes Planus, Insole, Orthosis.

\section{INTRODUCTION}

Acquired pes planus is a progressive and symptomatic deformity of foot that occurs as a result of dysfunction of structures that support medial longitudinal
Prihvaćen/Accepted 25. 07. 2018. god.

arch dynamically and statically (1). It is separated into two sub-groups as rigid and supple (2). Literature still hasn't reached a common consensus about its etiology; however posterior tibial tendon failure is considered to be the most common cause of supple pes planus (3).

Pes planus deformity might be asymptomatic; but it can also cause mechanic back pain by causing a chain reaction of kinetic and kinematic changes on lower extremity (4). Asymptomatic supple pes planus can be kept under control with patient education, using appropriate footwear, weight loss, and patient follow-ups; however with symptomatic patient's activity modification, orthosis use, and stretching exercises are required. In cases of severe pain non-steroidal anti-inflammatory drugs may be prescribed and/or a physical therapy program may be initiated. In cases where there is a lack of adequate response to the conservative treatment surgical procedures that target bone structure and/or soft tissue may be considered (5-8).

Different types of orthosis can be used in accordance to severity of complaints and deformity in patients with pes planus. Pre-made insoles that are produced from materials like silicon, ethyl vinylacetate (EVA) are often preferred because of accessibility and cost. However there are also custom-made or partially custom-made insoles available commercially. In custom made insoles for pes planus deformity the aim is to correct foot composition by placing different combinations of forefoot medial wedge, heel medial wedge, and longitudinal and transverse arch supports in different heights according to specific requirements in a mold produced for foot measurements of the patient (9). Other methods such as using a negative model that is created by covering foot with cast bandage or pressing foot in pedilen foam or $\mathrm{Cad} / \mathrm{Cam}$ method are also used in production of insoles (10). 
Hardness of the material used in insole is also a very important factor for usability and effectiveness. To be able to show correcting effect the insole must be hard; and for it to be able to show balanced weight distribution the insole must have shock-absorbing properties. In studies moderate and high density EVA or polyurethane are mostly preferred $(10,11)$. Footwear used is closely related to effectiveness and patient's continued usage of the insole. Insole's capability of staying stable in footwear and its part covering around the heel being hard enough to resist bending are basic factors required for the control of the calcaneal movement. Velcro or lace sports shoes or trekking shoes produced for nature walks are preferred (12).

As discussed above patient's gain from the insole and the time it will be used is depend on factors such as production method, production materials and the footwear used in conjunction with the insole. In this study we aimed to study the insole usage time and factors that impact this in patients diagnosed with pes planus.

\section{MATERIAL AND METHOD}

Files of the patients who were diagnosed with pes planus and prescribed insoles were identified and scanned retrospectively. Patients whose plantar pressures were measured and, their custom-made EVA insoles produced in accordance to these measurements were included. Patient's demographics, whether they use the insole or not, and their insole usage times were recorded. Patients who didn't use or ceased using the insoles were questioned about the reasons and time. After the data was recorded, association between insole usage rates and demographic data, and patients who used insole were compared.

Statistical analyses were performed on Windows based SPSS 15.0 package software, $p$ was $\leq 0.05$. Variables acquired from measurements were described as mean standard deviation. Q-square and t-tests were used for statistical analyses.

\section{RESULTS}

136 patients were included in this study. 56 were male, 86 were female. Sociodemographic data of the patients were shown in Table $1.86(63 \%)$ patients used insole for 6 months or more, $15(11 \%)$ used insole for less than 6 months. 35 patients $(26 \%)$ never used the insole even though they acquired it (Figure 1).

Mean age for patients who used and didn't use the insole were $32.80 \pm 18.64$ and $40.77 \pm 15.54$ respectively. Patients who kept using insole were younger $(\mathrm{p}=$ 0.04 ). Rates of patients who didn't use insole were $14.3 \%$ and $33.8 \%$ for males and females respectively

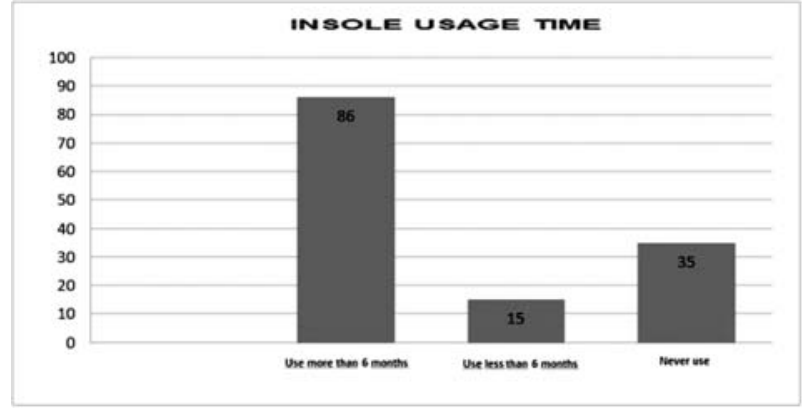

Figure 1. Insole usage time and number of patient

Table 1. Patient sociodemoghraphics $(n=136)$

\begin{tabular}{|c|c|c|}
\hline Variables & & \\
\hline \multirow{2}{*}{$\operatorname{Sex}(n, \%)$} & Female & $80, \% 59$ \\
\hline & Male & $56, \% 41$ \\
\hline \multirow{2}{*}{$\operatorname{Age}(\mathrm{Mt} \pm \mathrm{SD})$} & Using insole & $32.80 \pm 18.14$ \\
\hline & Not using insole & $40.77 \pm 12.54$ \\
\hline \multirow{2}{*}{$\begin{array}{l}\text { Usage time (months) } \\
(\mathrm{M} \pm \mathrm{SD})\end{array}$} & Female & $6.70 \pm 5.04$ \\
\hline & Male & $8.64 \pm 5.94$ \\
\hline \multirow{2}{*}{$\mathrm{VKI}(\mathrm{Ort} \pm \mathrm{SS})$} & Female & $24.5 \pm 4.52$ \\
\hline & Male & $24.4 \pm 3.89$ \\
\hline \multirow{3}{*}{$\begin{array}{l}\text { Reason for stopping } \\
\text { nsole usage } n,(\%)\end{array}$} & Insole is hard & $25, \% 18$ \\
\hline & $\begin{array}{c}\text { Can't use with } \\
\text { footwear of choice }\end{array}$ & $16, \% 12$ \\
\hline & $\begin{array}{l}\text { Increase in pain } \\
\text { or discomfort }\end{array}$ & $4, \% 3$ \\
\hline Constant usage $\mathrm{n},(\%)$ & & $86, \% 63$ \\
\hline $\begin{array}{l}\text { Inconstant usage } n \text {, } \\
(\%)\end{array}$ & & $5, \% 4$ \\
\hline
\end{tabular}

(Table 1). Rate of not using insole in female patients compared to male patients was statistically significant $(p=0.04)$. No association between insole usage, and weight, height and BMI was found ( $p>0.05)$.

45 patients haven't used their insoles. Most common reason presented was that the insole was too hard. Second most common reason presented was that the insole didn't fit the footwear of choice (Table 1).

\section{DISCUSSION AND CONCLUSION}

Insoles are frequently used inconservative treatment of pes planus for re-establishing the medial arch and increase foot stability. However questions such as "Are insoles therapeutically effective?", "Are patients happy with insole usage?", and "What are the reasons behind not using the insole?" are still unanswered. In this study we aimed to study the insole usage time and factors that impact this in our 136 patients who were diagnosed with pes planus and were prescribed with in- 
soles. We found that patients who haven't used insoles were of more advanced aged and rates for not using was higher for women compared to men.

Some patients doesn't use insoles regardless of potential gains. In a study investigating causes of this assessments were made under three main categories: (1) usability, (2) communication with health care professionals, and (3) views of other people. In this study of 23 patients it was concluded the most important reason of not using insole was usability. It was concluded that if the insole was providing the requirements of patient, improve his/her mobility, reduce the pain, and provide comfort usability increases paralelly (13). In our study 29 patients felt their pain increased because the insole was too hard and ceased usage. In our study we found that most common reason for cease of usage was usability.

In a meta-analysis consisting of 11 different randomized controlled trials, in line with ISO standards, usability was assessed under 4 main categories (efficacy, effectiveness, satisfaction and status of use). In all these studies efficacy was evaluated but effectiveness, satisfaction and status of usage were evaluated in 1, 5 and 3 studies respectively. Since only few studies included all four of the categories under usability, no conclusion on which parameter is more impactful on orthosis usage was reached (14).

In another meta-analysis which focuses on patient compliance with orthosis and orthopedic shoes, 10 studies were included (1576 patients). It was recorded that $6-80 \%$ of the patients weren't using the prescribed orthosis. Rates for not using was highest for AFO and lowest for orthopedic shoes. In four studies the most important reason was that the device was aesthetically unacceptable. Other important reasons were difficulty of usage, pain during use, unsatisfactory rates of relief in walking, and discomfort. Rate for dissatisfaction in orthopedic shoes was higher for women. This was attributed to women's higher amount of aesthetic concerns (15). In our study rates for not using insole was higher for women. But since the insoles were invisible to outside eyes we attributed this to discomfort rather than aesthetic concerns.

There is a close relationship between patient's continued usage the orthotic device and acceptance of said device. Most important reason against acceptance of the device is that it is visible to the outside. Visible device reminds the patient and people around him about his condition. If the patient makes peace with his condition and comes to the terms of acceptance with the condition and the device, then it could be used properly $(16,17)$.

107 patients suffering from diabetic ulcers were prescribed with custom made insoles and their time of usage for insoles and their step counts while using insole were calculated. It was seen that patients preferred to use the insole more frequently while being outside compared to while being at home (18). In our study 14 patients stated that they stopped using insole because they were unable to use the footwear of their choice. If the patients is spending more time at home compared to outside insole must also be used at home in order to reduce the severity of symptoms. So making the insole appropriate for usage with a footwear suitable for home use or prescribing different insoles for home and outside usage will improve usability.

There are discrepancies between the results of papers which investigate the association between device usage and age. In his study Haworth and Hopkins (19) found that device compliance in older patients was better compared to younger ones. In contrast Geiger (20) found that compliance of age group 60-69 was lower. Other studies reported no association between device usage andage $(21,22)$. In our study we observed that patients who used insole were younger than patients who didn't use insoles. Most striking aspect about this situation is that most common complaint of the older patients who didn't use insoles was a lack of comfort stemming from hardness. In older patients insole usage times is lowercompared to younger patients due to time they spent at home is higher compared to younger patients.

Another important factor about device usage is doctor-patient communication. If the complaints are taken into account and the patient is allowed to express himself comfortably; confidence in the physician increases while also increasing patient compliance (23). Also only way to understand the complaints and expectations of the patient is establishing a strong communication.

In the end, every patient who uses insoles shares the same purpose: to be able to walk with comfort like before, and become free and independent again. If the insole does not meet these expectations of the patient and/or patient achieves his purpose by other means, the insole will be left to gather dust. This leads to an increase in health-care costs, patient problem left unsolved and a lack of professional satisfaction for health-care professionals who work in orthosis-prosthesis field. Performing a comprehensive patient evaluation, informing the patient about all available treatment choices, involving him in the process of treatment and making sure a device meets the patient expectations while being aesthetically acceptable, will increase the device compliance and usage time.

\section{DECLARATION OF INTEREST}

The autors declare that there are no conflicts of interests.

\section{Licensing}

This work is licensed under a Creative Commons Attribution 4.0 International (CC BY 4.0) License. 


\title{
Sažetak
}

\section{FAKTORI KOJI UTIČU NA KORIŠĆENJE ULOŽAKA ZA OBUĆU KOD PACIJENATA SA PES PLANUS-om}

\author{
Erem Murat, ${ }^{1}$ Acikgoz Tahsin, ${ }^{2}$ Tastekin Nurettin, ${ }^{3}$ Sut Necdet ${ }^{4}$ \\ ${ }^{1}$ Trakya University, Faculty of Medicine, Department of Orhopedics and Traumatology, Edirne, Turkey \\ ${ }^{2}$ Prosthetics and orthotics technician, Prosthetics and Orthotics Production Center, Edirne, Turkey \\ ${ }^{3}$ Trakya University, Faculty of Medicine, Department of Physical Medicine and Rehabilitation, Edirne, Turkey \\ ${ }^{4}$ Trakya University, Faculty of Medicine, Department of Biostatistics, Edirne, Turkey
}

Uvod: Ulošci za obuću i program vežbi su glavni način lečenja kod pacijenata sa pes planusom. Ulošci mogu da preveniraju stvaranje bolova tokom dnevnih aktivnosti, kao i da povećaju kvalitet hoda. Cilj ove studije bio je da se napravi korelacija između vremena korišćenja kao i drugih faktora kod pacijenata sa pes planusom.

Material i metode: 136 pacijenata koji su dobili uloške je bilo uključeno u studiju. Pacijenti su uključeni u studiju preko telefonskog poziva. Demografske karakteristike pacijenata, vreme korišćenja uložaka, razlog i vreme nekorišćenja uložaka su uzeti u razmatranje. Stope korišćenja uložaka kao i demografski podaci pacijenata su upoređivani.

Rezultati: Od 136 pacijenata koji su bili uključeni u studiju, žena je bilo 80 (59\%), a muškaraca 56 (31\%). 86 ovih pacijenata je koristilo uloške preko šest

\section{REFERENCES}

1. Richie DH Jr. Biomechanics and clinical analysis of the adult acquired flatfoot. Clin Podiatr Med Surg. 2007; 24(4): 617-44.

2. Luhmann SJ, Rich MM, Schoenecker PL. Painful idiopathic rigid flatfoot in children and adolescents. Foot Ankle Int. 2000; 21(1): 59-66.

3. Walters JL, Mendicino SS. The flexible adult flatfoot: anatomy and pathomechanics. Clin Podiatr Med Surg. 2014; 31(3): 329-36.

4. Kosashvili Y, Fridman T, Backstein D, Safir O, Ziv YB. The correlation between pes planus and anterior knee or intermittent low back pain. Foot Ankle Int. 2008; 29(9): 910-3.

5. Lee MS, Vanore JV, Thomas JL, Catanzariti AR, Kogler G, Kravitz SR, et al. Diagnosis and treatment of adult flatfoot. J Foot Ankle Surg. 2005; 44(2): 78-113.

6. Bowring B, Chockalingam N. Conservative treatment of tibialis posterior tendon dysfunction - A review. Foot. 2010; 20(1): 18-26.

7. Marzano R. Nonoperative management of adult flatfoot deformities. Clin Podiat Med Surg. 2014; 31(3): 337-47.

8. Parsons S, Naim S, Richards P, McBride D. Correction and prevention of deformity in type II tibialis posterior dysfunction. Clin Orthop Relat Res. 2010; 468(4): 1025-32.

9. Vicenzino B. Foot orthotics in the treatment of lower limb conditions: a musculoskeletal physiotherapy perspective. Man Ther. 2004; 9(4): 185-96.

10. Crabtree P, Dhokia V, Newman S, Ansell M. Manufacturing methodology for personalised symptom-specific sports meseci, 15 ih je koristilo kraće od 6 meseci, a 35toro je kupilo, ali nije koristilo (63\%, 11\% i 26\% respektivno). Prosečni uzrast pacijenata koji su koristili uloške bio je 32,80 $\pm 18,14$ a onih koji nisu koristili 40,77 \pm $12,54(p=0,04) .33,8$ \% žena i $14,3 \%$ muškaraca nije koristilo uloške. Ova razlika je bila statistički značajna $(p=0,04)$. Nismo našli statističku značajnost ni u jednom parametru od interesa, kao što je visina, težina, BMI i korišćenje uložaka $(\mathrm{p}>0,05)$.

Zaključak: Korišćenje uložaka u lečenju pacijenata sa pes planusom je široko prihvaćena metoda lečenja na koju mogu da utiču demografski parametri kao što su pol i godine starosti. Pored udobnosti nošenja, ženski pol i starija životna dob trebaju se uzeti u razmatranje kao faktori koji utiču na korišćenje uložaka.

Ključne reči: pes planus, uložak, ortoza.

insoles. Robotics and Computer-Integrated Manufacturing. 2009; 25(6): 972-9.

11. Tong J, Ng EY. Preliminary investigation on the reduction of plantar loading pressure with different insole materials (SRP - Slow Recovery Poron, P-Poron, PPF-Poron+ Plastazote, firm and PPS-Poron+ Plastazote, soft). Foot (Edinburgh, Scotland). 2010;20(1): 1-6.

12. McPoil TG Jr. Footwear. Phys Ther. 1988; 68(12): 1857-65.

13. van Netten JJ, Dijkstra PU, Geertzen JH, Postema K. What influences a patient's decision to use custom-made orthopaedic shoes? BMC Musculoskelet Disord. 2012; 13:92.

14. Jannink MJ, Van Dijk H, De Vries J, Groothoff JW, Lankhorst GJ. A systematic review of the methodological quality and extent to which evaluation studies measure the usability of orthopaedic shoes. Clin Rehabil. 2004; 18(1): 15-26.

15. Swinnen E, Kerckhofs E. Compliance of patients wearing an orthotic device or orthopedic shoes: A systematic review. J Bodyw Mov Ther. 2015; 19(4): 759-70.

16. Wielandt T, Mckenna K, Tooth L, Strong J. Factors that predict the post-discharge use of recommended assistive technology (AT). Disabil Rehabil: Assist Technol. 2006;1 (1-2): $29-40$.

17. Wessels R, Dijcks B, Soede M, Gelderblom G, De Witte L. Non-use of provided assistive technology devices, a literature overview. Technology and disability. 2003; 15(4): 231-8.

18. Waaijman R, Keukenkamp R, de Haart M, Polomski WP, Nollet F, Bus SA. Adherence to wearing prescription custom-made footwear in patients with diabetes at high risk for plantar foot ulceration. Diabetes care. 2013; 36(6): 1613-8. 
19. Haworth R, Hopkins J. Use of aids following total hip replacement. The British Journal of Occupational Therapy. 1980; 43(12): 398-400.

20. Geiger CM. The utilization of assistive devices by patients discharged from an acute rehabilitation setting. Physical \& occupational therapy in geriatrics. 1990; 9(1): 3-25.

\section{Correspondence to/Autor za korespondenciju} Murat EREM, MD

Telephone: +905055720677

Fax : +902842233314

e-mail: muraterem83@hotmail.com

Adress: Trakya Universitesi Tip Fakultesi

Ortopedi ve Travmatoloji AD

Edirne, Turkey
21. Haworth R. Use of aids during the first three months after total hip replacement. Rheumatology. 1983; 22(1): 29-35.

22. Shipham I. Bath aids-their use by a multi-diagnostic group of patients. Int Rehabil Med. 1986; 8(4): 182-4.

23. Johnson M, Newton P, Goyder E. Patient and professional perspectives on prescribed therapeutic footwear for people with diabetes: a vignette study. Patient Educ Couns. 2006; 64(1): 167-72. 